\begin{tabular}{|c|c|c|c|}
\hline$a^{7}$ & $\begin{array}{r}\text { Anna } \\
\text { http://w }\end{array}$ & $\begin{array}{l}\text { Journal } \\
\text { /index.php }\end{array}$ & (1) \\
\hline & Print ISSN : 2278-9839 & Online ISSN : 2393-9885 & 84 \\
\hline
\end{tabular}

Original article

\title{
Thin-layer chromatography and in vitro free radical scavenging activity of few medicinal plants from the surroundings of Junagadh, Gujarat, India
}

\author{
Punit R. Bhatt, Urvesh D. Patel , Chirag M. Modi, Kajal B. Pandya and Harshad B. Patel \\ Department of Veterinary Pharmacology and Toxicology, College of Veterinary Science and Animal Husbandry, \\ Junagadh Agricultural University, Junagadh-362001, Gujarat, India
}

Received March 5, 2019: Revised April 25, 2019: Accepted April 27, 2019: Published online June 30, 2019

\begin{abstract}
A collection of medicinal plants was done from the ambience of Junagadh district, Gujarat, India. These plants were subsequently screened to know their phytochemical potential. The in vitro antioxidant activity was also evaluated using DPPH and nitric oxide scavenging methods. Qualitative phytochemical screening and total phenolic content have been evaluated for each plant extract. TLC showed the presence of various phytochemicals like alkaloids, flavonoids, phenolics, glycosides, saponins, sterols and tannins. Methanol and water extracts of plants exhibited the highest amount of phenolic content. There was a difference in per cent inhibition of DPPH and nitric oxide scavenging activity showed by extracts. In the case of DPPH scavenging activity, water extracts of Peltophorum pterocarpum (DC.) K. Heyne leaves and Syzygium cumini (L.) Skeels leaves showed the highest free radical inhibition up to $76.37 \pm 0.42 \%$ and $67.49 \pm 0.51 \%$, respectively. In the case of nitric oxide scavenging action, all the extracts of Bauhinia variegata L. bark and P. pterocarpum leaves showed nitric oxide inhibition more than $75 \%$. The plants like B. variegata, P. pterocarpum and S. cumini revealed high level of phenolic compounds. In conclusion, extracts of $B$. variegata, P. pterocarpum and $S$. cumini leaves can be served as the vital source of phenoilcs and flavonoids for having antioxidant potential.
\end{abstract}

Keywords: Antioxidant, DPPH, in vitro study, medicinal plants, nitric oxide, TLC

\section{Introduction}

Antioxidant compounds play a vital role as a health protecting factor. The primary source of these antioxidant compounds are fruits, vegetables and whole grains. The main role of antioxidant is to catalyze the simple redox reactions which occur in various biochemical processes by saturating lone-pair from free radicals, also called reactive oxygen species (ROS). These ROSs are highly reactive and able to initiate many degenerative diseases such as coronary heart disease, inflammation, stroke, diabetes mellitus and cancer. Antioxidant compounds which mainly include polyphenols, phenolic acids, etc., are commonly found in the plants (Brown and Rice-Evans, 1998; Scalbert et al., 2005).

Human and other organisms of our body have an antioxidant defence system in the form of enzyme, metal chelating or free radical scavenging activities to prevent or reduce the ROS inducing oxidative damage. In addition, dietary antioxidants help to maintain the antioxidant status in the body. Antioxidants neutralize the free radicals by accepting or donating electron (s) to eliminate the lone pair of the radical. The antioxidant molecules are directly reacting

\footnotetext{
Author for correspondence: Dr. U.D. Patel

Associate Professor, Department of Veterinary Pharmacology and Toxicology, College of Veterinary Science and Animal Husbandry, Junagadh Agricultural University, Junagadh-362001. Gujarat, India E-mail: urvesh1981@yahoo.com

Tel.: +91-9725003818
}

with reactive radical to destroy them and become new free radical itself, which are less reactive, less dangerous than the previous radical and longer-lived. Again, these radicals are neutralized by other free radical by a same or different mechanism and these reactions keep on going (Lü Jian-Ming et al., 2010).

Although, synthetic antioxidants are available, their role has been criticized. Antioxidants obtained from natural sources, mainly from medicinal plants are very good agents. In the last few decades, the focus on natural antioxidant compounds has increased (Jayaprakash and Rao, 2000). Medicinal plants serve as a readymade source of the antioxidant compounds which are not harmful, economical and easily available. In India, it is estimated that 17,000 plant species exist and among these, 2000 species of medicinal plants are used by several ethnic communities in India for their medicinal properties (Mahendra et al., 2016). Drugs of herbal origin provide a rational means for the treatment of several ailments in human and animals (Rajeshwari et al., 2013; Manoharachary and Nagaraju, 2016; Nayanabhirama, 2016). A number of medicinal herbs are established antioxidants such as ginseng, curcuma, ginkgo, rosemary, green tea, grape, ginger and garlic, etc. They contain a wide variety of antioxidant compounds which include phenols, flavonoids, carotenoids, steroids and thiols (Lü Jian-Ming et al., 2010). Potential role of herbal plants or phytomedicine in the area of oxidative stress has also been studied through in vitro or in vivo studies (Bhadarka et al., 2018; Shaul et al., 2018; Modi et al., 2018).

There are many medicinal plants in and around Junagadh, Gujarat, India which may have an antioxidant potential. The present study 
was carried out for evaluation of the in vitro antioxidant potential of 10 medicinal plants using DPPH (2, 2-diphenyl-1picrylhydrazyl) and nitric oxide scavenging methods along with phytochemical analysis through thin layer chromatography.

\section{Materials and Methods}

\subsection{Collection and processing of plant material}

All the plant materials as per Table 1 were collected from the surroundings of Junagadh, Gujarat, India. Collected plant materials were identified and authenticated by Pharmacognosist. A specimen of each plant material was deposited in the Department of Veterinary Pharmacology and Toxicology, Veterinary College, JAU, Junagadh. Voucher specimen number of each plant is mentioned in Table 1. Collected plant materials were washed with tap water and dried in an oven at $45^{\circ} \mathrm{C}$ for 2 to $3 \mathrm{~h}$. The material was ground; fine powder was made and stored in an air-tight container until use.

Table 1: List of medicinal plants used for evaluation of antioxidant activity

\begin{tabular}{|c|c|c|c|c|}
\hline $\begin{array}{l}\text { Sr. } \\
\text { No. }\end{array}$ & Plant species (Specimen No.) & Family & $\begin{array}{l}\text { Local name } \\
\text { (Gujarati) }\end{array}$ & $\begin{array}{l}\text { Part of } \\
\text { plant used }\end{array}$ \\
\hline 1 & Adansonia digitata L.(JVC/VPT/SP/PS/04/2015) & Bombacaceae & Gorakh ambali & Fruit \\
\hline 2 & Annona squamosa L.(JVC/VPT/SP/PS/01/2014) & Annonaceae & Sitaphali & Leaves \\
\hline 3 & Bauhinia variegata L.(JVC/VPT/SP/PS/05/2015) & Caesalpiniaceae & Kachanar & Bark \\
\hline 4 & Cassia tora L.(JVC/VPT/SP/PS/07/2015) & Calsalpiniaceae & Kuwadiyo & Leaves \\
\hline 5 & Curcuma amada Roxb.(JVC/VPT/SP/PS/06/2015) & Zingiberaceae & Amba haldar & Rhizomes \\
\hline 6 & Derris indicia (Lam.) Bennet (JVC/VPT/SP/PS/09/2015) & Fabaceae & Karanj & Seed \\
\hline 7 & Peltophorum pterocarpum (DC.) K. Heyne (JVC/VPT/SP/PS/11/2015) & Caesalpiniaceae & Pilo gulmohar & Leaves and bark \\
\hline 8 & Punica granatum L.(JVC/VPT/SP/PS/17/2015) & Punicaceae & Daadam & Epicarp \\
\hline 9 & Solanum xanthocarpum Schrad. \& H. Wendl. (JVC/VPT/SP/PS/18/2015) & Solanaceae & Bhoi ringani & Aerial part \\
\hline 10 & Syzygium cumini (L.) Skeels (JVC/VPT/SP/PS/12/2015) & Myrtaceae & Kala jambu & Leaves \\
\hline
\end{tabular}

Table 2: Per cent yield and appearance of the different extracts of medicinal plants

\begin{tabular}{|c|c|c|c|}
\hline Name of plant (Common names) & Extract & Appearance & $\%$ Yield \\
\hline \multirow[t]{3}{*}{ Adansonia digitata (Fruit) } & $\mathrm{CE}$ & Green sticky mass & 2.32 \\
\hline & ME & Green mass & 4.88 \\
\hline & WE & Dark brown solid & 10.60 \\
\hline \multirow[t]{3}{*}{ Annona squamosa (Leaf) } & $\mathrm{CE}$ & Green sticky mass & 4.92 \\
\hline & ME & Brownish mass & 7.92 \\
\hline & WE & Dark brown solid & 8.24 \\
\hline \multirow[t]{3}{*}{ Bauhinia variegata (Bark) } & $\mathrm{CE}$ & Green sticky mass & 1.80 \\
\hline & ME & Dark red mass & 4.40 \\
\hline & WE & Red solid mass & 13.00 \\
\hline \multirow[t]{3}{*}{ Cassia tora (Leaf) } & $\mathrm{CE}$ & Green sticky mass & 3.48 \\
\hline & ME & Brownish mass & 6.60 \\
\hline & WE & Dark brown solid & 8.76 \\
\hline \multirow[t]{3}{*}{ Curcuma amada (Rhizomes) } & $\mathrm{CE}$ & Colorless sticky mass & 1.16 \\
\hline & ME & Yellowish mass & 3.72 \\
\hline & WE & Yellow solid mass & 6.72 \\
\hline \multirow[t]{3}{*}{ Derris indica (Seed) } & $\mathrm{CE}$ & Colorless sticky mass & 1.44 \\
\hline & ME & Yellowish mass & 4.08 \\
\hline & WE & Light brown mass & 7.96 \\
\hline \multirow[t]{3}{*}{ Peltophorum pterocarpum (Leaf) } & $\mathrm{CE}$ & Green sticky mass & 1.56 \\
\hline & ME & Brownish mass & 4.96 \\
\hline & WE & Dark brown & 9.16 \\
\hline \multirow[t]{3}{*}{ Peltophorum pterocarpum (Bark) } & $\mathrm{CE}$ & Colorless sticky mass & 1.00 \\
\hline & $\mathrm{ME}$ & Dark red mass & 6.56 \\
\hline & WE & Dark red slid & 15.16 \\
\hline \multirow[t]{3}{*}{ Punica granatum (Epicarp) } & $\mathrm{CE}$ & Green sticky mass & 2.88 \\
\hline & ME & Brownish mass & 6.52 \\
\hline & WE & Dark brown & 7.80 \\
\hline \multirow[t]{3}{*}{ Solanum xanthocarpum (Aerial part) } & $\mathrm{CE}$ & Green sticky mass & 2.04 \\
\hline & ME & Brownish mass & 6.16 \\
\hline & WE & Dark brown & 8.40 \\
\hline \multirow[t]{3}{*}{ Syzygium cumini (Leaf) } & $\mathrm{CE}$ & Light green sticky mass & 2.12 \\
\hline & ME & Brownish mass & 8.40 \\
\hline & WE & Dark brown & 9.60 \\
\hline
\end{tabular}

$\mathrm{CE}=$ chloroform extract, $\mathrm{ME}=$ methanol extract, $\mathrm{WE}=$ water extract. 


\subsection{Preparation of extracts}

Fine powder of each plant material was defatted using n-hexane by Soxhlet apparatus to remove chlorophyll and other non-polar debris. The defatted plant material was dried in the oven below $45^{\circ} \mathrm{C}$. About $50 \mathrm{~g}$ of plant material was extracted with $500 \mathrm{ml}$ of chloroform, methanol and water separately at least two times. The content was filtered off and solvents were evaporated under reduced pressure using a rotary vacuum evaporator. The extracts were collected; yield was calculated and stored at $4^{\circ} \mathrm{C}$ for further use.

\subsection{Phytochemical screening}

Qualitative phytochemical screening was performed for each extract as per standard procedures (Harborne, 1998). Per cent yield and appearance of each plant extracts are shown in Table 2.

\subsection{Total phenolic content}

Total phenolic content was also measured by Folin Ciocalteu method (Encarnacão et al., 2015). In this assay, $250 \mu \mathrm{l}$ of extract solution was allowed to react with $2 \mathrm{ml}$ Folin-Ciocalteu (FC) reagent (previously diluted $1: 10)$ and $1 \mathrm{ml}$ solution $(75 \mathrm{~g} / \mathrm{l})$ of sodium carbonate. The mixture was allowed to stand for 1 to $2 \mathrm{~h}$. Absorbance was recorded at $760 \mathrm{~nm}$ in a spectrophotometer (Fusion Tek UV2900). Tests were performed in triplicate. Total phenolic content (TPC) was expressed as milligrams of gallic acid equivalent (GAE).

\subsection{Thin layer chromatography (TLC) of plants}

Thin layer chromatography (TLC) was performed to evaluate the presence of various phytochemicals in the different medicinal plant extracts used for the evaluation of an in vitro antioxidant activity The TLC of each plant extract was performed on $10 \times 10 \mathrm{~cm}$ precoated aluminium-backed silica gel plates $\mathrm{GF}_{254}$ (Merck, Darmstadt, Germany). The samples were applied as a band using Linomat 5 applicator (Camag, Germany).

\subsubsection{Detection of alkaloids}

About $2 \mathrm{~g}$ of powdered plant material of A. squamosa leaves, $C$. amada rhizomes, $S$. xanthocarpum aerial part, and $S$. cumini leaves was moisten with $1 \mathrm{ml}$ of strong ammonia and mixed thoroughly with mortar and pestle for $2 \mathrm{~min}$. Then, $7 \mathrm{~g}$ of silica gel (60-120 mesh) was added to this mass to get uniform cohesive mass. This mass was packed loosely in a glass column $2 \mathrm{~cm} \times 30 \mathrm{~cm}$. The column was eluted with $25 \mathrm{ml}$ of chloroform. The chloroform fraction collected in a beaker was evaporated to dryness. The dried mass was dissolved in methanol and used as samples. The plate was allowed to run in the pre-saturated mobile phase consist of toluene: ethyl acetate: diethylamine (7:2:1). After development, the plates were observed in the UV chamber to detect the presence of alkaloids (Wagner and Baldt, 1996) and dipped in drangendorff's reagent for the visualization of bands.

\subsubsection{Detection of glycosides}

Thin layer chromatography of glycosides was carried out as per the method given by Lokesh et al. (2017). Briefly, one gram of each dried plant material listed in Table 3 was extracted with $70 \%$ methanol by heating at $60^{\circ} \mathrm{C}$ for $10 \mathrm{~min}$. After cooling, the content was centrifuged to $2500 \mathrm{rpm}$ for $10 \mathrm{~min}$. Each supernatant was used as a sample for the detection of glycosides. The TLC plate was developed in a pre saturated mobile phase consist of ethyl acetate: methanol: water (20:2.5:2.5). The plate was observed in UV chamber at $366 \mathrm{~nm}$ light after spraying with Carr-Price reagent (20\% antimony (III) chloride in chloroform). The glycoside shows blue to violet fluorescence.

\subsubsection{Detection of saponin}

Dried plant material of $A$. digitata fruit, A. squamosa leaves and $S$. cumini leaves were extracted with $70 \%$ methanol with heating at $60^{\circ} \mathrm{C}$ for $10 \mathrm{~min}$. The content was centrifuged and the supernatant was dried, re-suspended in water containing a small amount of methanol, and shake with n-butanol (pre-saturated with water). An n-butanol layer was collected and used as TLC samples for the detection of saponin. The mobile phase consists of chloroform: glacial acetic acid: methanol: water (64:32:12:8). After development, the plate is sprayed with Carr-Price reagent (20\% antimony (III) chloride in chloroform). The saponin exhibits blue fluorescence in UV 365 (Wagner and Baldt, 1996; Waksmundzka-Hajnos, Sherma and Kowalska, 2008).

\subsubsection{Detection of tannins}

TLC of plant material for detection of tannins was carried out as per the method given by Helen et al. (2015). About $1 \mathrm{~g}$ of fine powder of each $B$. variegata bark, $P$. pterocarpum bark and $P$. granatum epicarp was extracted with $10 \mathrm{ml}$ of $70 \%$ acetone solution in $15 \mathrm{ml}$ polypropylene tubes. After vigorous shaking and sonication, the tubes were centrifuged at $2500 \mathrm{rpm}$ for $10 \mathrm{~min}$ to get the clear supernatant. The volume was reduced to $1 / 3$ and used as samples. The samples were applied to the TLC plates as bands. The plate was developed in mobile phase consist of toluene: acetone: formic acid (60:60:10) pre-saturated for $30 \mathrm{~min}$. Gallic acid $(0.5$ $\mathrm{mg} / \mathrm{ml}$ in methanol) and tannic acid $(0.5 \mathrm{mg} / \mathrm{ml}$ in methanol) were used as reference standard compounds. After development, the plates were sprayed with a $3 \%$ methanolic ferric chloride solution. The spots turn into dark bluish black against a light yellow background in daylight (Richter, 2002).

\subsubsection{Detection of sterols}

TLC of S. xanthocarpum aerial part and B. variegata bark for detection of phytosterol was carried out. One gram plant powder of the plants was extracted with $10 \mathrm{ml}$ of 9:1 v/v mixture of petroleum ether: methanol in a beaker using sonication for $10 \mathrm{~min}$. After sonication, the extract was filtered off and evaporated to dryness. The residues left over were dissolved in methanol and used as samples. The elution was carried out in n-hexane: diethyl ether (7:3 $\mathrm{v} / \mathrm{v})$. After development, the plate was sprayed with $50 \%$ methanolic sulfuric acid. After drying of the plates, the plates were observed in the UV chamber at $366 \mathrm{~nm}$.

\subsubsection{Detection of flavonoids}

The plant extracts for the detection of flavonoids were prepared by extracting $2 \mathrm{~g}$ of each plant material in $10 \mathrm{ml}$ of methanol on ultrasonic bath for $10 \mathrm{~min}$. Then, the extracts were centrifuged to $2500 \mathrm{rpm}$ for $10 \mathrm{~min}$, supernatants were collected and used as a sample. Both quercetin (Sigma-Aldrich, India) and rutin (SD Fine Ltd, India) were dissolved in methanol at a concentration $(0.5 \mathrm{mg} / \mathrm{ml})$.

Two different solvent systems were used for the detection of quercetin and rutin and related phytochemicals in the plant extracts, viz., ethyl acetate: formic acid: glacial acetic acid: water (100:11:11:26) for the detection of rutin (Wagner and Bladt, 1996) 
while n-hexane: ethyl acetate: glacial acetic acid (31:14:5) for the detection of quercetin (Medic-Saric et al., 2004) and related compounds in each plant extract. The samples were applied from 1 $\mathrm{cm}$ from the edge of the plate and allowed to run up to $8 \mathrm{~cm}$. Derivatization was achieved by spraying natural product reagent (1\% diphenyl boryloxye thylamine in methanol followed by $5 \%$ polyethylene glycol-4000 in methanol). The plates were then observed in the UV cabinet (Camag, Germany) at $366 \mathrm{~nm}$.

\subsubsection{Detection of phenolic compounds}

The presence of phenolic compounds with special reference to gallic acid was detected with TLC as per the method is given by Shah et al. (2016). The plant powder (1 g) of each plant was extracted with $8 \mathrm{ml}$ methanol on sonication for $10 \mathrm{~min}$. After sonication, the content was centrifuged and the supernatant was collected, reduced the volume to $1 / 3$, and used as samples. The chromatographic separation was achieved in the mobile phase consists of toluene: ethyl acetate: formic acid: water $(6: 6: 1.2: 0.25)$. After the development of bands up to $8 \mathrm{~cm}$, the plates were dried and sprayed with natural product reagent (1\% diphenylboryloxyethylamine in methanol followed by $5 \%$ polyethylene glycol-4000 in methanol). The plates were then observed in the UV cabinet (Camag, Germany) at $366 \mathrm{~nm}$.

The $R_{f}$ values (Retention factor) of each separated bands and standard compounds were calculated using dividing distance travelled by each solute to the total solvent front $(8 \mathrm{~cm})$.

\subsection{Antioxidant activity}

\subsubsection{DPPH scavenging activity}

Three $\mathrm{ml}$ of each extract concentrations/ascorbic acid solution were taken in the glass test tubes. One $\mathrm{ml}$ of $0.1 \mathrm{mM}$ DPPH solution (4 $\mathrm{mg}$ in $100 \mathrm{ml}$ methanol) was added. The solution was kept for $30 \mathrm{~min}$ at room temperature until the colour changed from violet to yellowish violet to yellow. Absorbance at $517 \mathrm{~nm}$ in spectrophotometer was recorded. A blank solution containing distilled water and DPPH alone (Control) were also prepared and spectra were recorded for control purpose. Ascorbic acid was used as the standard antioxidant compound. All tests were performed in triplicate (Senguttuvan et al., 2014).

\subsubsection{Nitric oxide scavenging activity}

Three $\mathrm{ml}$ of all concentrations of prepared extracts were added with $500 \mu \mathrm{l}$ of $10 \mathrm{mM}$ sodium nitroprusside solution and kept for $3 \mathrm{~h}$. The mixture was added with $250 \mu \mathrm{l}$ Griess reagent $(1 \%$ sulphanilamide, $2 \%$ orthophosphoric acid, $0.1 \% \mathrm{~N}$-1-naphthylethyelediamine di-hydrochloride [NED]) which produced pink colour in the solution. The mixture was allowed to stand for $30 \mathrm{~min}$ at room temperature and the absorbance at $546 \mathrm{~nm}$ in spectrophotometer was recorded. Antioxidant activity of both the assays was measured by calculating $\%$ inhibition against a range of concentrations. \% inhibition can be calculated as follow: \% inhibition $=(1-\mathrm{A} c / \mathrm{A} t) 100$; where $\mathrm{A} c$ is absorbance of control; $\mathrm{A} t$ is absorbance of the test. Ascorbic acid was used as standard antioxidant compound (Senguttuvan et al., 2014).

\subsection{Statistical analysis}

All the data are represented as Mean \pm SE. Data DPHH and nitric oxide scavenging activity were analyzed by one-way analysis of variance (one-way ANOVA), followed by Duncan Multiple Range Test (DMRT).

\section{Results}

Phytochemical screening was performed as per standard methods and various phytochemicals detected by chemical methods. Extracts of $A$. squamosa leaf, $C$. amada rhizome, S. cumini leaf and $S$. xanthocarpum aerial part showed presence of alkloids. Extracts of $B$. variegata bark, $P$. granatum fruit epicarp and $P$. pterocarpum bark were found with presence of tannins. Flavanoids were detected in extracts of $A$. digitata fruit, A. squamosa leaf, B. variegata bark, $C$. amada rhizome, $C$. tora leaf, D. indica seed, P. pterocarpum leaf, $P$. pterocarpum bark, $P$. granatum fruit epicarp, S. cumini leaf, and $S$. xanthocarpum aerial part (Table 3). Methanol and water extract of B. variegata (bark), P. pterocarpum (leaf and bark), $P$. granatum (epicarp) and S. cumini (leaf) were found with high total phenolic content (Table 4). Comparatively, methanolic and water extract of $P$. pterocarpum (leaf and bark) showed higher phenolic content about 47 and $50 \mathrm{mg}$ GAE per gram, respectively. Different $R_{f}$ values of alkaloid detected are shown in Table 5 and Figure 1.

Table 3: Phytochemical screening of different extracts of medicinal plants

\begin{tabular}{|c|c|c|}
\hline Sr. No. & Name of phytochemical & Name of medicinal plants \\
\hline 1. & Alkaloid & $\begin{array}{l}\text { A. squamosa leaf extract, C. amada rhizome extract, S. cumini leaf extract, } \\
\text { S. xanthocarpum aerial part extract }\end{array}$ \\
\hline 2. & Glycoside & $\begin{array}{l}\text { A. digitata fruit extract, } B \text {. variegata bark extract, } C \text {. amada rhizome extract, } C \text {. tora } \\
\text { leaf extract, } D \text {. indica seed extract, } P \text {. pterocarpum leaf extract, } P \text {. pterocarpum bark } \\
\text { extract, } P \text {. granatum fruit epicarp extract, } S \text {. xanthocarpum aerial part extract }\end{array}$ \\
\hline 3. & Saponin & A. digitata fruit extract, A. squamosa leaf extract, $S$. cumini leaf extract \\
\hline 4. & Tannin & B. variegata bark extract, $P$. granatum fruit epicarp extract, $P$. pterocarpum bark extract \\
\hline 5 . & Sterol & B. variegata bark extract, $S$. xanthocarpum aerial part extract \\
\hline 6. & Phenolic compounds & $\begin{array}{l}\text { A. digitata fruit extract, } A \text {. squamosa leaf extract, } B \text {. variegata bark extract, } C \text {. amada } \\
\text { rhizome extract, } C \text {. tora leaf extract, } D \text {. indica seed extract, } P \text {. pterocarpum leaf extract, } \\
P \text {. pterocarpum bark extract, } P \text {. granatum fruit epicarp extract, } S \text {. cumini leaf extract, } S \text {. } \\
\text { xanthocarpum aerial part extract }\end{array}$ \\
\hline 7. & Flavonoids & $\begin{array}{l}\text { A. digitata fruit extract, } A \text {. squamosa leaf extract, } B \text {. variegata bark extract, } C \text {. amada } \\
\text { rhizome extract, } C \text {. tora leaf extract, } D \text {. indica seed extract, } P \text {. pterocarpum leaf extract, } \\
P \text {. pterocarpum bark extract, } P \text {. granatum fruit epicarp extract, } S \text {. cumini leaf extract, } S \text {. } \\
\text { xanthocarpum aerial part extract. }\end{array}$ \\
\hline
\end{tabular}


Table 4: Total phenolic content (mg GAE per gram) of different extracts of medicinal plants

\begin{tabular}{|c|c|c|}
\hline Name of plant & Extract & $\begin{array}{l}\text { Total phenolic } \\
\text { content (mg GAE } \\
\text { per gram) }\end{array}$ \\
\hline \multirow[t]{3}{*}{ Adansonia digitata (Fruit) } & $\mathrm{CE}$ & $4.89 \pm 0.01$ \\
\hline & ME & $2.54 \pm 0.11$ \\
\hline & WE & $0.08 \pm 0.21$ \\
\hline \multirow[t]{3}{*}{ Annona squamosa (Leaf) } & $\mathrm{CE}$ & $1.61 \pm 0.17$ \\
\hline & ME & $7.87 \pm 0.23$ \\
\hline & WE & $2.58 \pm 0.08$ \\
\hline \multirow[t]{3}{*}{ Bauhinia variegata (Bark) } & $\mathrm{CE}$ & $3.05 \pm 0.08$ \\
\hline & ME & $47.41 \pm 5.29$ \\
\hline & WE & $36.42 \pm 0.54$ \\
\hline \multirow[t]{3}{*}{ Cassia tora (Leaf) } & $\mathrm{CE}$ & $4.89 \pm 0.11$ \\
\hline & ME & $8.99 \pm 0.14$ \\
\hline & WE & $4.68 \pm 0.17$ \\
\hline \multirow[t]{3}{*}{ Curcuma amada (Rhizomes) } & $\mathrm{CE}$ & $9.75 \pm 0.10$ \\
\hline & ME & $2.92 \pm 0.19$ \\
\hline & WE & $2.58 \pm 0.08$ \\
\hline \multirow[t]{3}{*}{ Derris indica (Seed) } & $\mathrm{CE}$ & $1.04 \pm 0.10$ \\
\hline & ME & $3.19 \pm 0.08$ \\
\hline & WE & $2.09 \pm 0.14$ \\
\hline \multirow[t]{3}{*}{ Peltophorum pterocarpum (Leaf) } & $\mathrm{CE}$ & $7.50 \pm 0.07$ \\
\hline & ME & $41.98 \pm 0.11$ \\
\hline & WE & $72.73 \pm 0.50$ \\
\hline \multirow[t]{3}{*}{ Peltophorum pterocarpum (Bark) } & $\mathrm{CE}$ & $6.32 \pm 0.12$ \\
\hline & ME & $47.22 \pm 0.15$ \\
\hline & WE & $50.53 \pm 0.08$ \\
\hline \multirow[t]{3}{*}{ Punica granatum (Epicarp) } & $\mathrm{CE}$ & $1.90 \pm 0.11$ \\
\hline & ME & $29.19 \pm 0.18$ \\
\hline & WE & $38.62 \pm 0.01$ \\
\hline Solanum xanthocarpum & $\mathrm{CE}$ & $1.98 \pm 0.16$ \\
\hline \multirow[t]{2}{*}{ (Aerial part) } & ME & $4.90 \pm 0.12$ \\
\hline & WE & $5.98 \pm 0.11$ \\
\hline \multirow[t]{3}{*}{ Syzygium cumini (Leaf) } & $\mathrm{CE}$ & $2.02 \pm 0.13$ \\
\hline & ME & $36.47 \pm 0.09$ \\
\hline & WE & $16.59 \pm 0.24$ \\
\hline
\end{tabular}

$\mathrm{CE}=$ chloroform extract, $\mathrm{ME}=$ methanol extract, $\mathrm{WE}=$ water extract, $\mathrm{GAE}=$ Gallic Acid Equivalent

Table 5: $R_{f}$ values of alkaloids detected in plants

\begin{tabular}{|l|l|}
\hline Name of extract/plant & $\mathbf{R}_{\mathrm{f}}$ values \\
\hline A. squamosa (Leaf) & $0.57,0.97$ \\
C. amada (Rhizome) & $0.03,0.98$ \\
S. cumini (Leaf) & $0.58,0.75$ \\
S. xanthocarpum (Aerial part) & $0.03,0.99$ \\
\hline
\end{tabular}

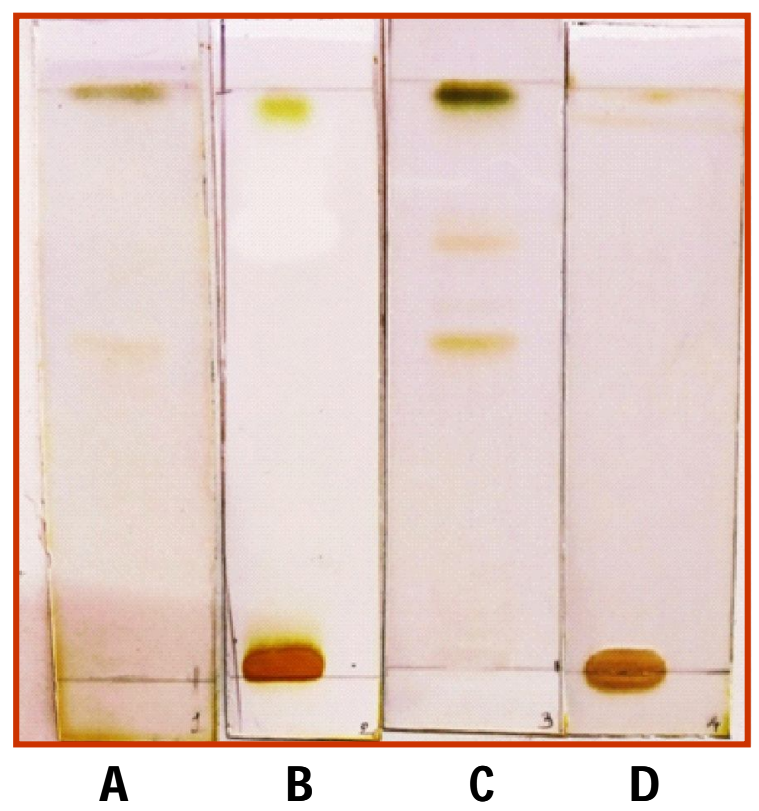

Figure 1: Detection of alkaloids by TLC in plants; $\mathrm{A}=$ A. squamosa leaves; $\mathrm{B}=C$. amada rhizome; $\mathrm{C}=S$. cumini leaves; $\mathrm{D}=$ S. xanthocarpum aerial parts.

TLC of various plant extracts exhibited the presence of glycosides, saponins, tannins, phytosterol, phenolic compounds and flavonoids. $\mathrm{R}_{\mathrm{f}}$ values of glycosides, saponins, tannins, phytosterol, phenolic compounds and flavonoids are shown in Table 6 to Table 11, respectively. Detected glycosides, saponins, tannins, phytosterol and phenolic compounds are shown in Figure 2 to 6, respectively. $P$. pterocarpum (leaf), $P$. pterocarpum (bark), P. granatum (fruit epicarp), $S$. cumini (leaf) and $S$. xanthocarpum (aerial part) exhibited the presence of gallic acid with $\mathrm{R}_{\mathrm{f}}$ value of 0.52 . The $C$. tora (leaf) extract was found with presence of quercetin with $R_{f}$ value of 0.23 with the solvent system of $n$-hexane: ethyl acetate: glacial acetic acid (31:14:5). Rutin was also deteceted in C. tora (leaf) and $A$. squamosa (leaf) extract with $\mathrm{R}_{\mathrm{f}}$ value of 0.53 with the solvent system of ethyl acetate: formic acid: glacial acetic acid: water (100:11:11:26) (Table 11, Figure 7 and 8).

Table 6: $R_{f}$ values of glycosides detected in plants

\begin{tabular}{|l|l|}
\hline Name of extract/plant & $\mathbf{R}_{\mathbf{f}} \mathbf{v a l u e s}$ \\
\hline A. digitata (Fruit) & $0.025,0.53,0.58$ \\
B. variegata (Bark) & 0.025 \\
C. amada (Rhizome) & $0.025,0.21,0.31,0.38,0.5$, \\
C. tora (Leaf) & 0.66 \\
D. indica (Seed) & $0.025,0.65,0.9$ \\
P. pterocarpum (Leaf) & $0.025,0.91$ \\
P. pterocarpum (Bark) & $0.65,0.9$ \\
P. granatum (Fruit epicarp) & $0.63,0.71$ \\
S. xanthocarpum (Aerial part) & $0.16,0.38,0.72$ \\
\hline
\end{tabular}


Table 7: $\mathrm{R}_{\mathrm{f}}$ values of saponin detected in plant extracts

\begin{tabular}{|l|l|}
\hline Name of extract/plant & $\mathbf{R}_{\mathrm{f}}$ values \\
\hline A. digitata (Fruit) & $0.13,0.28,0.47,0.66$ \\
A. squamosa (Leaf) & $0.17,0.23,0.26,0.36$, \\
& $0.42,0.58,0.63,0.72,0.82$ \\
S. cumini (Leaf) & $0.35,0.53,0.63,0.73$, \\
& $0.78,0.82,0.9$ \\
\hline
\end{tabular}

Table 8: $R_{f}$ values of tannin detected in plant

\begin{tabular}{|l|l|}
\hline Name of extract/standard & $\mathbf{R}_{\mathrm{f}}$ values \\
\hline P. granatum (Fruit epicarp) & $0,0.22,0.7$ \\
Gallic acid & 0.7 \\
Tannic acid & $0,0.22,0.26,0.7$ \\
\hline
\end{tabular}

Table 9: $\mathrm{R}_{\mathrm{f}}$ values of phytosterol detected in plant

\begin{tabular}{|l|l|}
\hline Name of extract/plant & $\mathbf{R}_{\mathbf{f}}$ values \\
\hline B. variegata (Bark) & 0.95 \\
S. xanthocarpum (Aerial part) & $0.13,0.23,0.95$ \\
\hline
\end{tabular}

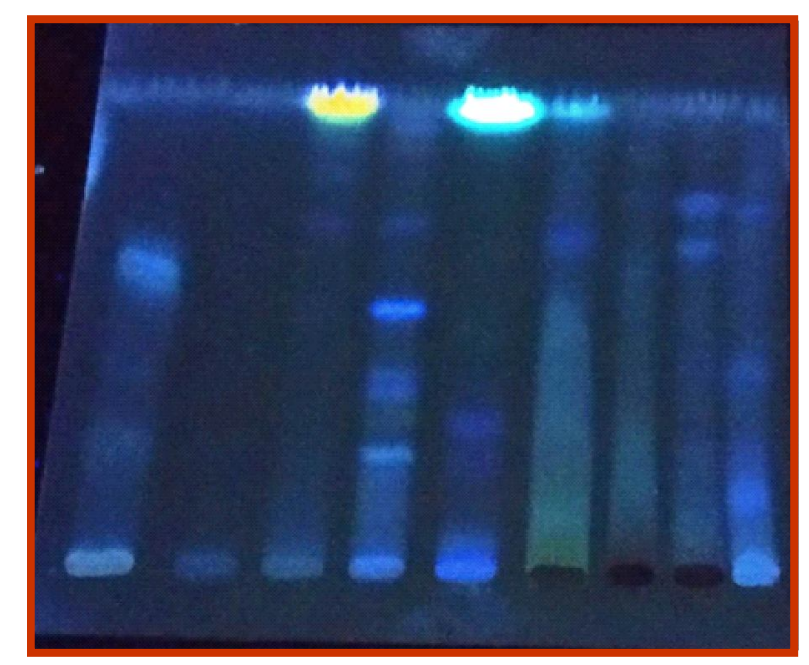

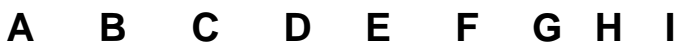

Figure 2: Detection of glycosides by TLC in plants; $\mathrm{A}=A$. digitata fruit; $\mathrm{B}=B$. variegata bark; $\mathrm{C}=C$. tora leaf; $\mathrm{D}=C$. amada rhizome; $\mathrm{E}=D$. indica fruit; $\mathrm{F}=P$. pterocarpum leaf; $\mathrm{G}=$ $P$. pterocarpum bark; $\mathrm{H}=P$. granatum fruit epicarp; $\mathrm{I}=S$. xanthocarpum aerial part.

Water extract of $P$. pterocarpum leaves, water extract of $B$. variagata bark, water extract of $S$. cumini leaves and methanol as well as chloroform extract of $S$. cumini leaves showed more DPPH scavenging activity as compared to extracts of other plant materials used in the study (Figure 9). Chloroform extract of B. variagata bark, water extract of $B$. variagata bark, methanol extract of $B$. variagata bark where all types of extracts of $P$. pterocarpum leaves showed more nitric oxide scavenging activity compared to other extracts used in the study (Figure 10 and 11).
Table 10: $R_{f}$ values of phenolic compounds detected in plant

\begin{tabular}{|c|c|}
\hline Name of extract/standard & $R_{f}$ values \\
\hline A. digitata (Fruit) & $0.03,0.06,0.11,0.61$ \\
\hline A. squamosa (Leaf) & $0.03,0.08,0.83,0.93$ \\
\hline B. variegata (Bark) & 0.61 \\
\hline C. amada (Rhizome) & $0.66,0.70,0.73$ \\
\hline C. tora (Leaf) & $\begin{array}{l}0.05,0.08,0.11,0.61,0.7 \\
0.81,0.9,0.95\end{array}$ \\
\hline D. indica (Seed) & $0.7,0.73,0.85$ \\
\hline P. pterocarpum (Leaf) & $\begin{array}{l}0.08,0.13,0.52 *, 0.65 \\
0.67,0.71,0.76,0.91\end{array}$ \\
\hline P. pterocarpum (Bark) & $\begin{array}{l}0.02,0.07,0.15,0.52 * \\
0.68,0.76,0.92\end{array}$ \\
\hline P. granatum (Fruit epicarp) & $\begin{array}{l}0.07,0.26,0.32,0.41 \\
0.52 * 0.7,0.73,0.8,0.85\end{array}$ \\
\hline S. cumini (Leaf) & $\begin{array}{l}0.07,0.11,0.21,0.28, \\
0.36,0.52 *, 0.62,0.7,0.72 \\
0.8,0.86,0.91\end{array}$ \\
\hline S. xanthocarpum (Aerial part) & $\begin{array}{l}0.03,0.06,0.38,0.52 * \\
0.71,0.78,0.83\end{array}$ \\
\hline Gallic acid (Standard) & 0.52 \\
\hline
\end{tabular}

* shows presence of gallic acid in plant
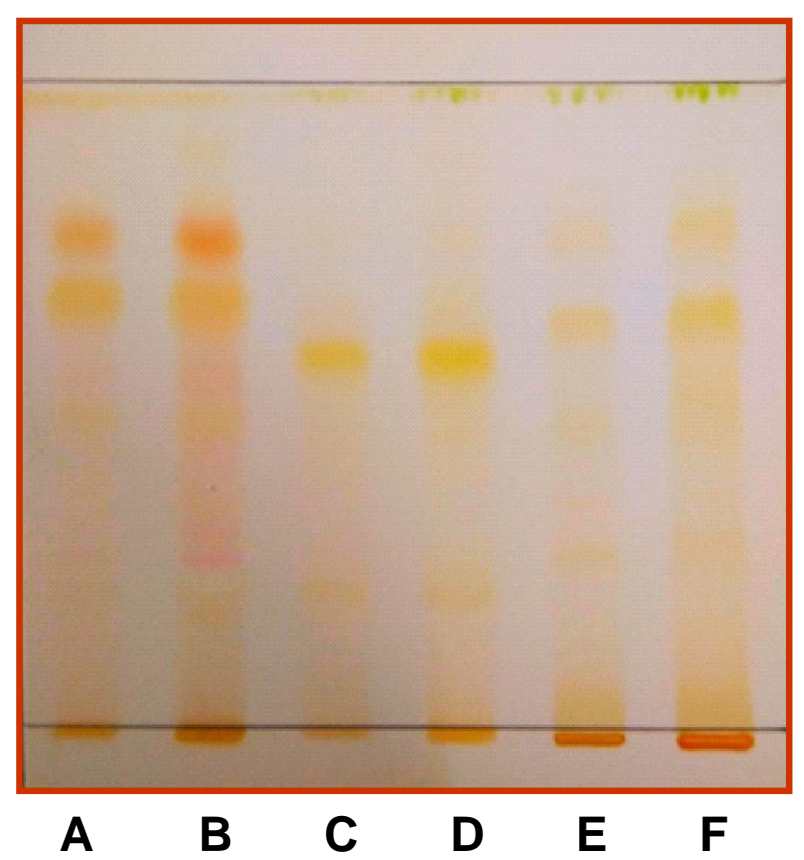

Figure 3: Detection of saponins by TLC in plants $\mathrm{A}$ and $\mathrm{B}=A$. digitata fruit $4 \mu \mathrm{l}$ and $8 \mu \mathrm{C}$ and $\mathrm{D}=A$. squamosa leaves $4 \mu \mathrm{l}$ and $8 \mu \mathrm{l} \mathrm{E}$ and $\mathrm{F}=S$. cumini leaves $4 \mu \mathrm{l}$ and $8 \mu \mathrm{l}$. 
Table 11: $R_{\mathrm{f}}$ values of flavonoids detected in plant

\begin{tabular}{|l|l|l|}
\hline Name of extract/plant & $\mathbf{R}_{\mathrm{f}}$ values $^{\mathbf{a}}$ & $\mathbf{R}_{\mathrm{f}}$ values $^{\mathbf{b}}$ \\
\hline A. digitata (Fruit) & 0.08 & $0.4,0.57,0.63,0.68$ \\
A. squamosa (Leaf) & $0.8,0.88$ & $0.2,0.32,0.53^{*}$ \\
B. variegata (Bark) & 0.47 & $0.46,0.88$ \\
C. amada (Rhizome) & 0.5 & $0.73,0.83$ \\
C. tora (Leaf) & $0.1,0.23^{*}, 0.3,0.45,0.48$ & $0.21,0.35,0.46,0.53^{*}, 0.72,0.82$ \\
D. indica (Seed) & $0.57,0.71,0.86,0.91$ & 0.45 \\
P. pterocarpum (Leaf) & $0.27,0.6,0.72,0.76,0.83,0.91,0.93$ & $0.43,0.52,0.58,0.65,0.76$ \\
P. pterocarpum (Bark) & $0.26,0.33,0.47,0.66,0.86,0.9$ & $0.41,0.48,0.56,0.6,0.77$ \\
P. granatum (Fruit epicarp) & $0.25,0.27,0.38,0.65,0.67,0.72,0.85$ & $0.47,0.8$ \\
S. cumini (Leaf) & $0.41,0.47,0.53,0.6,0.7,0.76,0.78,0.81,0.86,0.9$ & $0.63,0.78,0.86$ \\
S. xanthocarpum (Aerial part) & $0.27,0.41,0.63,0.71,0.82$ & $0.45,0.48,0.58,0.72,0.81$ \\
Quercetin & 0.23 & - \\
Rutin & - & 0.53 \\
\hline
\end{tabular}

a- $R_{f}$ values for solvent system $n$-hexane: ethyl acetate: glacial acetic acid (31:14:5)

b- Ethyl acetate: formic acid: glacial acetic acid: water (100:11:11:26)

* shows matching of presence of quercetin or rutin in plant

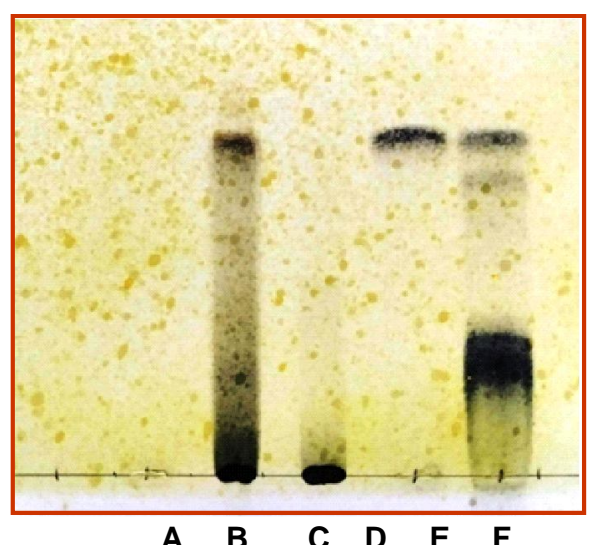

Figure 4: Detection of tannins by TLC in plants; $A=B$. variegata bark; $\mathrm{B}=P$. pterocarpum bark; $\mathrm{C}=P$. granatum fruit epicarp; $\mathrm{D}=$ gallic acid; $\mathrm{E}=$ tannic acid; $\mathrm{F}=$ mixture of tannin acid and gallic acid (increasing $\mathrm{R}_{\mathrm{f}}$ ).

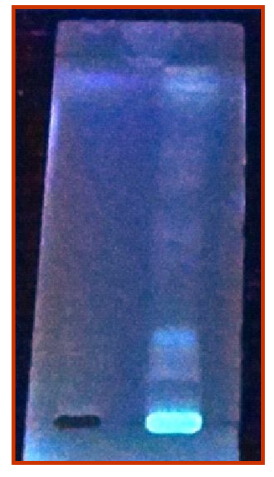

A B

Figure 5: Detection of sterol by TLC in plants; $\mathrm{A}=$ B. variegata bark; $\mathrm{B}=S$. xanthocarpum aerial part.

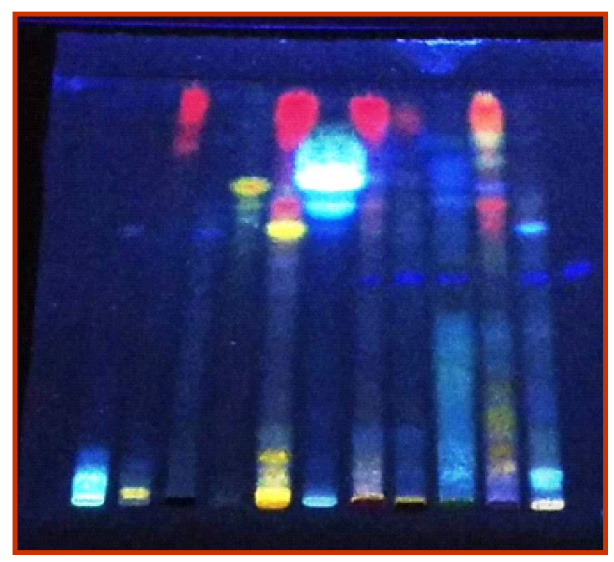

\section{A B C D E F G H I J K L}

Figure 6: Detection of phenolic compounds by TLC in plants; $\mathrm{A}=$ A. digitata fruit; $\mathrm{B}=A$. squamosa leaf; $\mathrm{C}=B$. variegata bark; $\mathrm{D}=C$. amada rhizome; $\mathrm{E}=C$. tora leaf; $\mathrm{F}=D$. indica fruit; $\mathrm{G}=P$. pterocarpum leaf; $\mathrm{H}=P$. pterocarpum bark; $\mathrm{I}=P$. granatum fruit epicarp; $\mathrm{J}=S$. cumini leaf; $\mathrm{K}=S$. xanthocarpum aerial part; $\mathrm{L}=$ galic acid

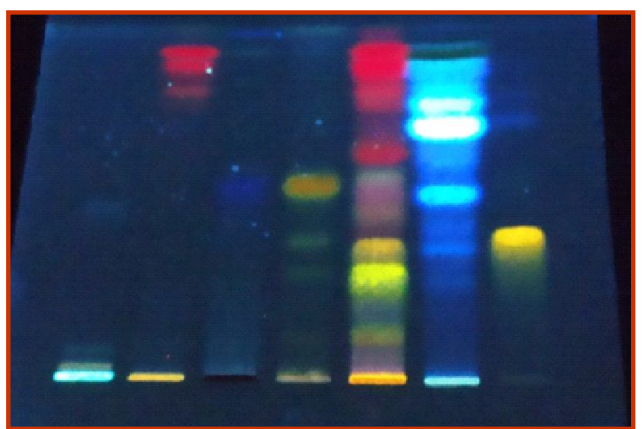

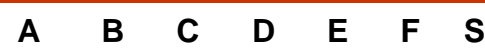




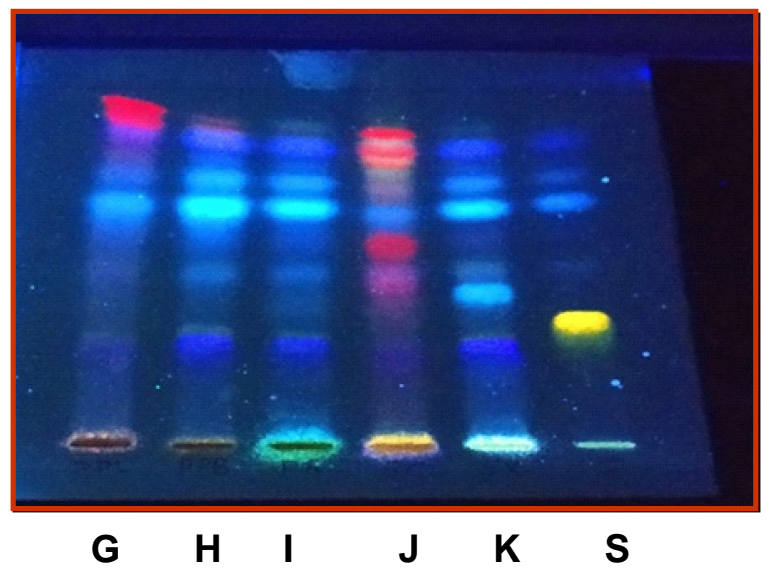

Figure 7: Detection of quercetin by TLC in plants; $\mathrm{A}=A$. digitata fruit; $\mathrm{B}=A$. squamosa leaf; $\mathrm{C}=B$. variegata bark; $\mathrm{D}=\mathrm{C}$. amada rhizome; $\mathrm{E}=\mathrm{C}$. tora leaf; $\mathrm{F}=D$. indica fruit; $\mathrm{G}=P$. pterocarpum leaf; $\mathrm{H}=P$. pterocarpum bark; $\mathrm{I}=P$. granatum fruit epicarp; $\mathrm{J}=S$. cumini leaf; $\mathrm{K}=S$. xanthocarpum aerial part; $\mathrm{S}=$ Quercetin.

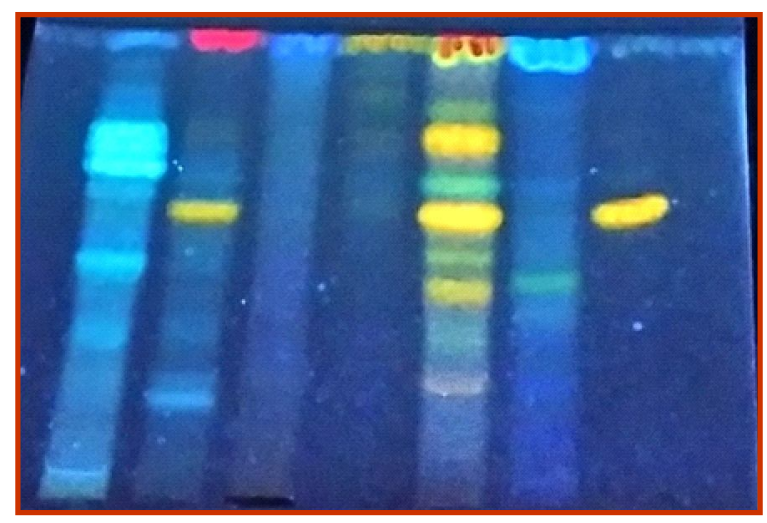

$\begin{array}{lllllll}A & B & C & D & E & F & S\end{array}$

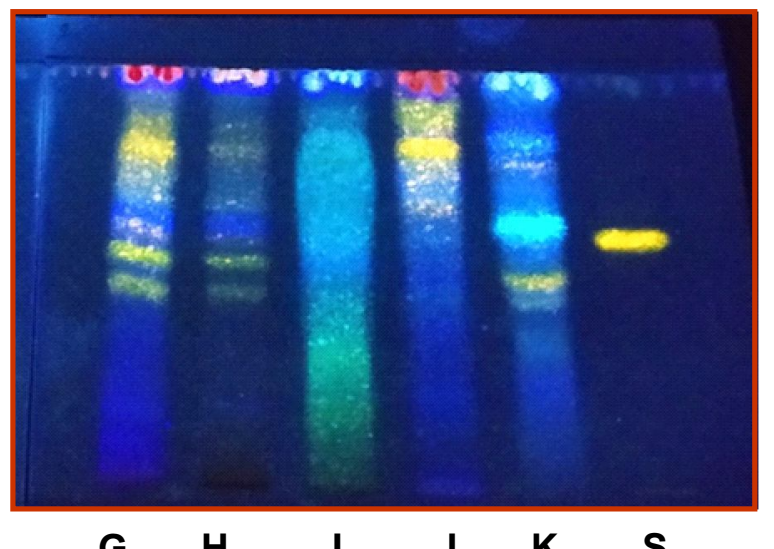

$\begin{array}{lllllll}\mathbf{G} & \mathbf{H} & \mathbf{I} & \mathbf{J} & \mathbf{K} & \mathbf{S}\end{array}$

Figure 8: Detection of rutin by TLC in plants; $\mathrm{A}=$ A. digitata fruit; $\mathrm{B}=A$. squamosa leaf; $\mathrm{C}=B$. variegata bark $; \mathrm{D}=C$. amada rhizome; $\mathrm{E}=C$. tora leaf; $\mathrm{F}=D$. indica fruit; $\mathrm{G}=$ $P$. pterocarpum leaf; $\mathrm{H}=P$. pterocarpum bark; $\mathrm{I}=P$. granatum fruit epicarp; $\mathrm{J}=S$. cumini leaf; $\mathrm{K}=S$. xanthocarpum aerial part; $\mathrm{S}=$ Rutin.

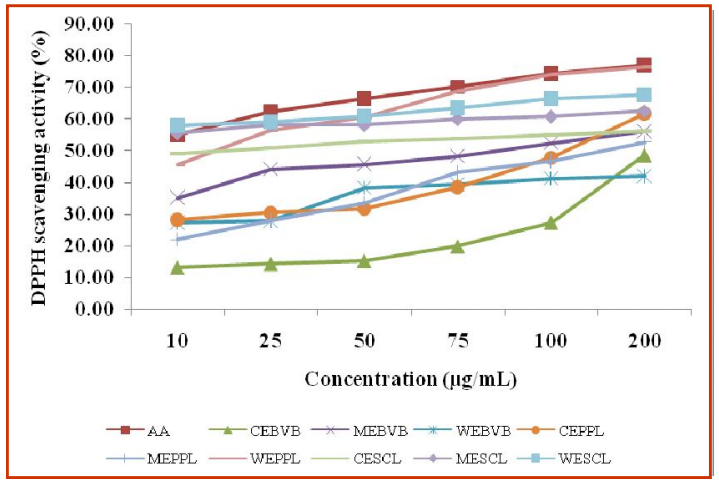

Figure 9: DPPH scavenging activity of different extracts of $B$. variagata bark, P. pterocarpum leaves, S. cumini leaves and ascorbic acid at various concentrations. (AA - Ascorbic acid; CEBVB - chloroform extract of $B$. variagata bark; MEBVB - methanol extract of $B$. variagata bark; WEBVBWater extract of B. variagata bark; CEPPL - chloroform extract of $P$. pterocarpum leaves; MEPPL - methanol extract of $P$. pterocarpum leaves; WEPPL - water extract of $P$. pterocarpum leaves; CESCL - chloroform extract of $S$. cumini leaves; MESCL - methanol extract of S. cumini leaves; WESCL - water extract of $S$. cumini leaves).

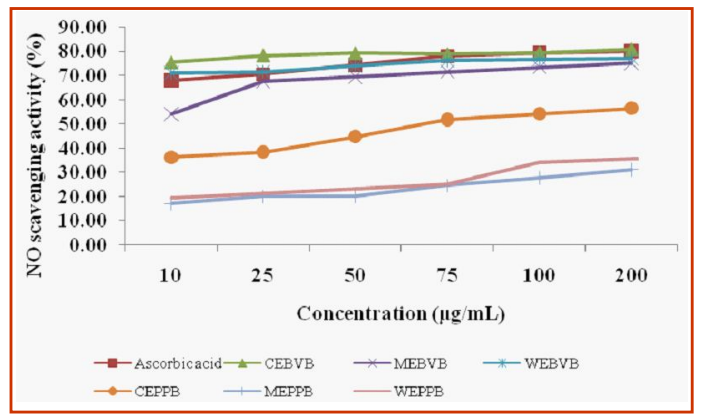

Figure 10: Nitric oxide scavenging activity of different extracts of $B$. variagata bark, P. pterocarpum bark and ascorbic acid at various concentrations (CEBVB - chloroform extract of $B$. variagata bark; MEBVB - methanol extract of $B$. variagata bark; WEBVB - water extract of $B$. variagata bark; CEPPB - chloroform extract of P. pterocarpum bark; MEPPB - methanol extract of $P$. pterocarpum bark; WEPPB - water extract of $P$. pterocarpum bark).

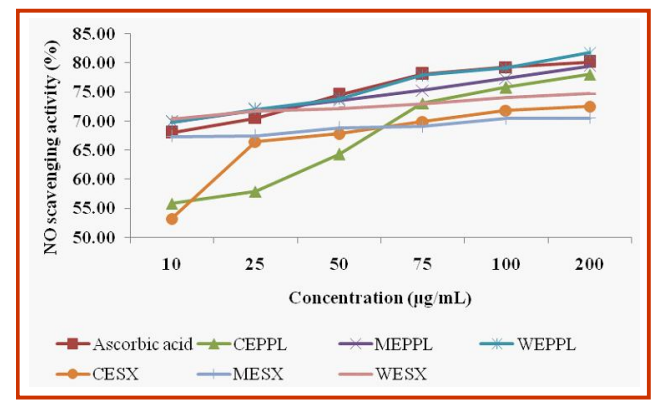

Figure 11: Nitric oxide scavenging activity of different extracts of P. pterocarpum leaves, S. xanthocarpum aerial part and ascorbic acid at various concentrations (CEPPL chloroform extract of $P$. pterocarpum leaves; MEPPL methanol extract of $P$. pterocarpum leaves; WEPPL - water extract of P. pterocarpum leaves; CESX - chloroform extract of $S$. xanthocarpum aerial part; MESX - methanol extract of $S$. xanthocarpum aerial part; WESX - water extract of $S$. xanthocarpum aerial part). 


\section{Discussion}

Phytochemical screening was performed as per standard tests. All these tests are qualitative which give an indication about the presence of particular phytochemical in the plant/extract based on the observation of either colour or secondary reactions. In the present study, total phenolic content (mg GAE per gram) in all plant extracts have also been determined. The Folin-Ciocalteu (FC) method is widely used to assay the total phenolic content (Folin and Ciocalteu, 1927). Total phenolic content can give an indirect idea about the antioxidant capacity of the plant extract (Oliveira et al., 2012). Water extract of P. pterocarpum bark showed the highest phenolic content $72.73 \mathrm{mg} / \mathrm{g}$ GAE. This is due to the presence of numerous phytochemicals like lupeol, $\beta$-sitosterol, leucocyanidin and bergenin, etc. (Jash et al., 2014). Few plants showed a lower level of total phenolic content which might be due to the presence of the fatty or organic compound. Apart from this, A. squamosa, S. xanthocarum and $S$. cumini exhibited the presence of alkaloid compound in different extracts.

Since one compound may have a different mechanism of antioxidant effect, so only one activity is not sufficient to describe the antioxidant activity of any test compound (Huang et al., 2005). DPPH scavenging action is the most widely used method for determination of antioxidant activity. DPPH dissolves in methanol or ethanol and has absorbance maxima at 515 or $519 \mathrm{~nm}$. When this free radical is scavenged, the colour of DPPH becomes lighter ( $\mathrm{Li}$ et al., 2009).

Out of ten plants, water extract of $P$. pterocarpum leaves showed inhibition of DPPH at $76.37 \pm 0.42 \%$ which was comparable $(p>$ $0.05)$ with ascorbic acid $(77.08 \pm 0.31 \%)$ at $200 \mu \mathrm{g} / \mathrm{ml}$. Devi and Battu (2018) reported that P. pterocarpum leaves are the rich source of flavonoids like naringenin, ophioglonin, kaempferol isorhamnetin, luteolin, chrysoeriol, quercetin, etc. Chew et al. (2011) also reported $P$. pterocarpum as a potential antioxidant plant from the Leguminosae family. S. cumini is one of the most widely used plants in many diseases in traditional medicine, particularly in diabetes. The plant has been reported with a number of phytochemicals like anthocyanins, glucoside, ellagic acid, isoquercetin, kaempferol and myricetin (Ayyanar and Subhashbabu, 2012). All these phytochemicals are strong antioxidants and might be responsible for the strong DPPH inhibition in methanol and water extract. Methanol and water extracts of $S$. cumini leaves produced inhibition up to $62.46 \pm 0.40 \%$ and $67.49 \pm 0.51 \%$, respectively. However, the activity of $S$. cumini leaves was significantly $(p<0.05)$ lower as compared to ascorbic acid at the highest concentration. The result from DPPH inhibition in the present study indicates that extracts of few possess the ability to donate protons to free radicals and, thus can be used as a source of antioxidants as the antioxidant effect of extracts on DPPH was might be due to their ability to donate hydrogen to free radicals.

The damage caused by nitric oxide and super oxide radicals is multiplied as they react to produce reactive peroxynitrile $\left(\mathrm{ONOO}^{-}\right.$ ), which leads to serious toxic reactions with biomolecules. Generally, reactive free radicals like nitric oxides produced at a cellular level and add more reactive species (e.g., peroxynitrite), which are decomposed to hydroxyl radicals. In the present study, all the extracts of $B$. variegata bark also exhibited relatively high nitric oxide inhibition at $200 \mu \mathrm{g} / \mathrm{ml}$ which was at par $(p>0.05)$ with per cent inhibition by ascorbic acid. Singh et al. (2016) reported the presence of a number of phytochemicals like kaempferol, lupeol and beta-sitosterol, isoquercitroside, rutoside myricetol glycoside and kaempferol glycosides, bauhinione, etc., in B. variegata stem bark which might cause the strong nitric oxide scavenging activity in the present study. Chloroform, methanol and water extract of $P$. pterocarpum leaves also exhibited inhibition of nitric oxide, 77.99 $\pm 0.34 \%, 79.49 \pm 0.23 \%, 81.77 \pm 0.58 \%$, respectively which were also at par $(p>0.05)$ with per cent inhibition by ascorbic acid. Numerous phytochemicals have been reported from the $P$. pterocarpum leaves which possess strong antioxidant actions like phenoxychromone derivatives and naringenin (Cavia-Saiz et al., 2010), ophioglonin, luteolin (Majewska et al., 2011), quercetin (Zhang et al., 2011), quercitrin, chrysoeriol (Mishra et al., 2003), etc. Similarly, all the extracts of $S$. xanthocarpum showed comparable inhibition $(p>0.05)$ as shown by ascorbic acid at 200 $\mu \mathrm{g} / \mathrm{ml}$. A special type of glycol-alkaloid name solasodine has been found in all parts of the plant which might be responsible for its antioxidant action (Koduru et al., 2007; Parmar et al., 2010).

The mechanism and working of both the assay; DPPH (1, 1-diphenyl2-picrylhydrazyl) and nitric oxide scavenging action are different. DPPH is a stable free radical which can be reduced to non-radical upon addition of one hydrogen molecule from the oxidized molecule (phytochemicals). Upon reduction the DPPH, produces stable yellow colour from dark violet colour and the intensity of colour is a measurement of ability of compound to scavenge the DPPH. That is why, the assay is sometimes referred to as free radical scavenging activity. The mechanism of nitric oxide assay is reverse of DPPH assay. In this case, nitric oxide is oxidized itself to become stable nitrate $\left(\mathrm{NO}_{3}-\right)$ and nitrite $\left(\mathrm{NO}_{2}-\right)$ under aerobic condition. The amount of stable ion can be detected quantitatively with the help of Griess reagent which produces pink colour by diazotization reaction (Alam et al., 2013).

In the present study, upon thin layer chromatographic analysis, quercetin, rutin, gallic acid, other flavonoid and phenolic compounds have been identified in a few plants. Flavonoids like quercetin and rutin are used for the prevention and treatment of various ailments due to oxidative stress. Flavonoid acts as an antioxidant in biological systems and scavenges the free radicals, leads to strengthening the antioxidant defence system in the body. Among polyphenolic compounds, several factors could be responsible for increasing radical scavenging effectiveness. Those factors are including orthodihydroxy structure in the $\mathrm{B}$ ring, 2,3-double bond in conjugation with a 4-oxo function in the C-ring, hydroxy groups in positions 3 and 5 in the A ring, or the angle between the rings in the compound structure (Dugas et al., 2000; Lopez-Vele et al., 2003; Pawlak et al., 2010). Presence of quercetin, rutin, gallic acid, other flavonoid and phenolic compounds in extracts of few plants might be responsible for their in vitro antioxidant activity.

\section{Conclusion}

Amongst, all plants selected and used to evaluate in vitro antioxidant activity in the present study, various extracts of B. variegata, $P$. pterocarpum and $S$. cumini showed remarkable DPPH scavenging activity. Various extracts of $B$. variegata and S. Xanthocarpum also showed nitric oxide scavenging activity comparable to ascorbic acid. The plants like B. variegata, P. pterocarpum and $S$. cumini have a higher level of phenolic or flavonoid compounds which are 
responsible for their antioxidant potential. The findings of the present study suggested that $B$. variegata bark, $P$. pterocarpum leaves, and $S$. cumini leaves may be a good source of natural antioxidant agents with great therapeutic importance for prevention of degenerative changes due to reactive oxygen species and associated oxidative stress condition.

\section{Conflict of interest}

The authors declare that no conflict of interest exists in the course of conducting this research. All authors had final decision regarding the manuscript and the decision to submit the findings for publication.

\section{References}

Alam, M.N.; Bristi, N.J. and Rafiquzzaman, M. (2013). Review on in vivo and in vitro methods evaluation of antioxidant activity. Saudi Pharmaceutical Journal, 21(2):143-152.

Ayyanar, M. and Subash-Babu, P. (2012). Syzygium cumini (L.) Skeels: A review of its phytochemical constituents and traditional uses. Asian Pacific Journal of Tropical Biomedicine, 2(3):240-246. https://doi.org/10.1016/S2221-1691(12)60050-1

Bhadarka, D.H.; Patel, U.D.; Shaul,A.R.; Patel, H.B.; Modi, C.M. and Fefar, D.T (2018). Biochemical and histological evaluation following multiple dose administration of paracetamol alone and along with polyherbal extract mixture in rats. Ann. Phytomed., 7(2):114-123.

Brown, J. E. and Rice-Evans C. A. (1998). Luteolin-rich artichoke extract protects low-density lipoprotein from oxidation in vitro. Free Radical Research, 29(3):247-255. https://doi.org/10.1080/ 10715769800300281

Cavia-Saiz, M.; Busto, M. D.; Pilar-Izquierdo, M. C.; Ortega, N.; Perez-Mateos, M. and Muñiz, P. (2010). Antioxidant properties, radical scavenging activity and biomolecule protection capacity of flavonoid naringenin and its glycoside naringin: A comparative study. Journal of the Science of Food and Agriculture, 90(7):1238-1244. https:/ /doi.org/10.1002/jsfa.3959

Chew, Y. L.; Ling Chan, E. W.; Tan, P. L.; Lim, Y. Y.; Stanslas, J. and Goh, J. K. (2011). Assessment of phytochemical content, polyphenolic composition, antioxidant and antibacterial activities of Leguminosae medicinal plants in Peninsular Malaysia. BMC Complementary and Alternative Medicine, 11(12):1-10. https:// doi.org/10.1186/1472-6882-11-12

Devi, D. R. and Battu, G. R. (2018). A phytochemical and pharmacological review on Peltophorum pterocarpum (dc.) Baker Ex. Heyne. World Journal of Pharmacy and Pharmaceutical Sciences, 7(6):166-176. https://doi.org/10.20959/wjpps20186-11327

Dugas, A.J.; Castaneda-Acosta, J.; Bonin, G.C.; Price, K.L.; Fischer, N.H. and Winston, G.W. (2000). Evaluation of total peroxyl radical-scavenging capacity of flavonoids: Structure activity relationships. J. Nat. Prod., 63:327-31.40.

Encarnação, S.; de Mello-Sampayo, C.; Graça, N. A. G.; Catarino, L.; da Silva, I. B. M.; Lima, B. S. and Silva, O. M. D. (2016). Total phenolic content, antioxidant activity and pre-clinical safety evaluation of an Anacardium occidentale stem bark Portuguese hypoglycemic traditional herbal preparation. Industrial Crops and Products, 82:171-178. https://doi.org/10.1016/j.indcrop.2015.11.001

Fernandes de Oliveira, A.; Sousa Pinheiro, L.; Souto Pereira, C.; Neves Matias, W.; Albuquerque Gomes, R.; Souza Chaves, O. and Simões de Assis, T. (2012) Total phenolic content and antioxidant activity of some Malvaceae family species. Antioxidants, 1(1):33-43.

Folin, O. and Ciocalteu, V. (1927). On tyrosine and tryptophane determinations in proteins. The Journal of Biological Chemistry, 73:627-650
Harborne, A. J. (1998). Phytochemical methods: A guide to modern techniques of plant analysis. $3^{\text {rd }}$ edn. Springer science, Netherland.

Helen, L. R., Jyothilakshmi, M. and Latha, M. S. (2015). Isolation and quantification of tannins from the root bark of Clerodendrum infortunatum Linn. and assessment of their antioxidant potential and antiproliferative effect on HCT-15 cells. International Journal of Pharmacy and Pharmaceutical Sciences, 7(10):170-175.

Huang, D.; Boxin, O. U. and Prior, R. L. (2005). The chemistry behind antioxidant capacity assays. Journal of Agricultural and Food Chemistry, 53:1841-1856. https://doi.org/10.1021/jf030723c

Jayaprakasha, G. K. and Jaganmohan Rao, L. (2000). Phenolic constituents from the lichen Parmotrema stuppeum (Nyl.) Hale and their antioxidant activity. Zeitschrift Fur Naturforschung - Section C Journal of Biosciences, 55(11-12):1018-1022. https://doi.org/ 10.1515/znc-2000-11-1227

Koduru, S.; Grierson, D. S.; Van De Venter, M. and Afolayan, A. J. (2007) Anticancer activity of steroid alkaloids isolated from Solanum aculeastrum. Pharmaceutical Biology, 45(8):613-618. https:// doi.org/10.1080/13880200701538690

Li, X.; Wu, X. and Huang, L. (2009). Correlation between antioxidant activities and phenolic contents of Radix, Angelicae Sinensis (Danggui). Molecules, 14(12):5349-5361. https://doi.org/10.3390/ molecules 14125349

Lokesh,T.; Dileep, K. K.; Gayathri, S.; Begum, M. S. and Rameshwar, R. K. (2017) A novel fingerprinting method for glycosides in nakshatra plants by HPTLC. J. Chromatogr. Sep. Tech., 8:382. doi: 10.4172/21577064.1000382

Lopez-Velez, M,; Martinez-Mertinez, F. and Valle-Ribes, C.D. (2003). The study of phenolic compounds as natural antioxidants in wine. Crit. Rev. Food Sci. Nutr., 43:233-244.

Lü, J. M.; Lin, P. H.; Yao, Q. and Chen, C. (2010). Chemical and molecular mechanisms of antioxidants: Experimental approaches and model systems. Journal of Cellular and Molecular Medicine, 14(4):840860. https://doi.org/10.1111/j.1582-4934.2009.00897.x

Mahendra, C.; Manasa, G.; Murali, M.; Amruthesh, K.N.; Sudarshana, M.S. and Lingaraju, D.P. (2016). Antibacterial and antioxidant properties of Argyreia osyrensis Roth. Ann. Phytomed., 5(1):110-115.

Majewska, M.; Skrzycki, M.; Podsiad, M. and Czeczot, H. (2011). Evaluation of antioxidant potential of flavonoids: An in vitro study. Acta Poloniae Pharmaceutica Drug Research, 68(4):611-615.

Manoharachary, C. and Nagaraj, D. (2016). Medicinal plants for human health and welfare. Ann. Phytomed., 5(1):24-34

Mediæ-Šariæ, M.; Jasprica, I; Smolèiæ-Bubalo, A and Mornar, A. (2004). Optimization of chromatographic conditions in thin-layer chromatography of flavonoids and phenolic acids. Croatica Chemica Acta, 77(1-2):361-366.

Mishra, B.; Priyadarsini, K. I.; Kumar, M. S.; Unnikrishnan, M. K. and Mohan, H. (2003). Effect of O-glycosilation on the antioxidant activity and free radical reactions of a plant flavonoid, chrysoeriol. Bioorganic and Medicinal Chemistry, 11(13):2677-2685. https://doi.org/ 10.1016/S0968-0896(03)00232-3

Modi, C.M.; Ladumor, V.C.; Patel, U.D.; Patel, H.B., Solanki, S.L and Bhadarka, D.H. (2018). Phytochemical analysis and comparative study of in vitro free radical scavenging activity of different extractsof leaves of Abrus precatorius L. Ann. Phytomed., 7(2):133-137.

Nayanabhirama Udupa (2016). Status on herbal drugs and their future properties. Ann. Phytomed., 5(1):1-3

Parmar, S.; Gangwal, A. and Sheth, N. (2010). Solanum xanthocarpum (Yellow Berried Night Shade): A review. Der Pharmacia Letter, 2(4):373-383. 
Pawlak, K.; Bylka, W.; Jazurek, B.; Matlawska, I.; Sikorska, M. and Manikowski, H. (2010). Antioxidant activity of flavonoids of different polarity, assayed by modified ABTS cation radical decolorization and EPR technique. Acta Biol. Crac. Ser. Bot., 52:97-104.39.

Rajeshwari, C.U., Shobha, R.I. and Andallu, B. (2013). Oxidative stress and antioxidant effects of herbs and spices in diabetes. Ann. Phytomed., 2(2):13-27.

Richter, J., Kabrodt, K., Schellenberg, I. (2002). Characterization of tannins from rhubarb by TLC/HPTLC. Camag Bibliographic Service, 88: 4-6.

Scalbert, A.; Manach, C.; Morand, C.; Rémésy, C. and Jiménez, L. (2005). Dietary polyphenols and the prevention of diseases. Critical Reviews in Food Science and Nutrition, 45:287-306. https://doi.org/10.1080/ 1040869059096

Senguttuvan, J.; Paulsamy, S. and Karthika, K. (2014). Phytochemical analysis and evaluation of leaf and root parts of the medicinal herb, Hypochaeris radicata $\mathrm{L}$. for in vitro antioxidant activities. Asian Pacific Journal of Tropical Biomedicine, 4:S359-S367. https:// doi.org/10.12980/APJTB.4.2014C1030.

Shaul, A.R.; Patel, U.D.; Bhadarka, D.H.; Patel, H.B. and Modi, C.M. (2018) Modulation of antioxidant defense system by polyherbal extract mixture which ameliorated the pathophysiological alterations in streptozotocin induced diabetic rats. Ann. Phytomed., 7(2):102113.
Shah, M. A.; Patel, H. and Raj, H. (2017). Methods for the estimation of ellagic acid and curcumin in antidiabetic herbal formulations : A Review. Eurasian Journal of Analytical Chemistry, 12(4):295-311. https://doi.org/10.12973/ejac.2017.00171a

Shyamal, K.; Jash Raj, K.; Singh; Sasadhar Majhi; Sakar, A. and Gorai, D. (2014). Peltophorum pterocarpum: Chemical and Pharmacological Aspects. International Journal of Pharmaceutical Sciences and Research, 5(1):26-36. https://doi.org/10.13040/IJPSR.0975$8232.5(1) \cdot 26-36$

Singh, L. K.; Sing, D. K. and Singh, V. K. (2016). Multidimensional uses of medicinal plant Kachnar (Bauhinia variegata Linn.). American Journal of Phytomedicine and Clinical Therapeutics, 4(2):058072 .

Wagner, H. and Bladt, S. (1996). Plant Drug Analysis: A Thin Layer Chromatography Atlas. $2^{\text {nd }}$ Edn. Springer-Verlag Berlin Heidelberg.

Waksmundzka-Hajnos, M., Sherma, J., Kowalska, T. (2008). Thin-layer chromatography in phytochemistry. In:Oleszek, W., Kapusta, I., Stochmal, A., (Eds.), TLC of Triterpenes (Including Saponins) (pp. 519-542). 99 ${ }^{\text {th }}$ Edn. Florida, USA. CRC press.

Zhang, M.; Swarts, S.G.; Yin, L.; Liu, C.; Tian, Y.; Cao, Y.; Swarts, M.; Yang, S.; Zhang, S.B.; Zhang, K.; Ju, S.; Olek, D.J. Jr Schwartz, L.; Keng, P.C.; Howell, R.; Zhang, L. and Okunieff, P. (2011). Antioxidant properties of quercetin. Advances in Experimental Medicine and Biology, 701: 283-289. https://doi.org/10.1007/978-1-4419-7756-4_38

Citation: Punit R. Bhatt, Urvesh D. Patel, Chirag M. Modi, Kajal B. Pandya and Harshad B. Patel (2019). Thin-layer chromatography and in vitro free radical scavenging activity of few medicinal plants from the surroundings of Junagadh, Gujarat, India. Ann. Phytomed., 8(1):45-55. 